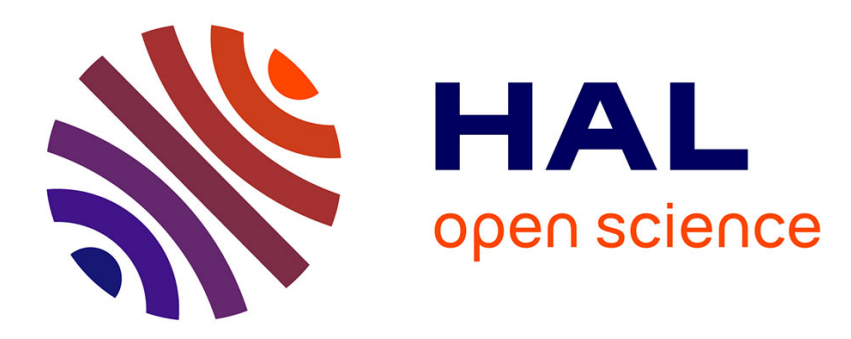

\title{
Dying for a Living: Economic and Moral Restructuring in a French Factory
}

Pascal Marichalar

\section{To cite this version:}

Pascal Marichalar. Dying for a Living: Economic and Moral Restructuring in a French Factory. History of the Present, 2018, 8 (2), pp.209-232. 10.5406/historypresent.8.2.0209 . halshs-02388777

\section{HAL Id: halshs-02388777 https://shs.hal.science/halshs-02388777}

Submitted on 10 Dec 2019

HAL is a multi-disciplinary open access archive for the deposit and dissemination of scientific research documents, whether they are published or not. The documents may come from teaching and research institutions in France or abroad, or from public or private research centers.
L'archive ouverte pluridisciplinaire HAL, est destinée au dépôt et à la diffusion de documents scientifiques de niveau recherche, publiés ou non, émanant des établissements d'enseignement et de recherche français ou étrangers, des laboratoires publics ou privés. 
Dying for a Living: Economic and Moral Restructuring in a French Factory

Author(s): Pascal Marichalar

Source: History of the Present, Vol. 8, No. 2 (Fall 2018), pp. 209-232

Published by: University of Illinois Press

Stable URL: https://www.jstor.org/stable/10.5406/historypresent.8.2.0209

\section{REFERENCES}

Linked references are available on JSTOR for this article:

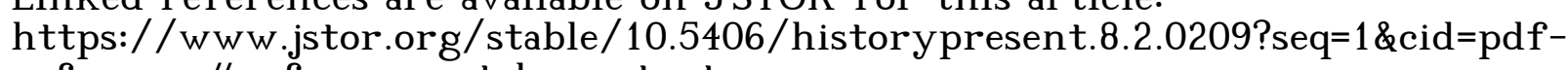

reference\#references_tab_contents

You may need to $\log$ in to JSTOR to access the linked references.

JSTOR is a not-for-profit service that helps scholars, researchers, and students discover, use, and build upon a wide range of content in a trusted digital archive. We use information technology and tools to increase productivity and facilitate new forms of scholarship. For more information about JSTOR, please contact support@jstor.org.

Your use of the JSTOR archive indicates your acceptance of the Terms \& Conditions of Use, available at https://about.jstor.org/terms 


\section{Dying for a Living: Economic and Moral Restructuring in a French Factory}

\section{Pascal Marichalar}

In 1897, after a decade of intense scholarly work, Max Weber suffered a nervous breakdown' ${ }^{1}$. For most of the six years that followed, a period which some have called his "lost years," he was no longer able to read or write without great distress. The sociologist "struggled to teach but often could not complete the semester," and "was unable to concentrate on work." ${ }^{2}$ Only in 1904 did he take up a new writing project, which led to him publishing The Protestant Ethic and the Spirit of Capitalism, the classic study that deals precisely with the mystery of how and why we commit ourselves to work. ${ }^{3} \mathrm{His}$ explanation involved the enduring legacy of ascetic Protestantism, what he called "the ghost of dead religious beliefs." ${ }^{\prime 4}$ In 1908, Weber completed this line of thought in a study of worker output in a textile factory-a study that also considered worldly factors such as wages, worker solidarity, and the threat of unemployment. ${ }^{5}$

Sociologists have never ceased to be obsessed with the question of consent in the workplace. Conducting fieldwork in the same industrial plant thirty years apart, Donald Roy and Michael Burawoy each dealt with this topic from different viewpoints: "Where [Roy] had been interested in why workers did not work harder, I wondered why they worked as hard as they did," Burawoy reflected retrospectively ${ }^{6}$. Burawoy's study, Manufacturing Consent, showed the importance of internal labor markets and what he called the internal state, "whose grievance machine constituted workers with rights and obligations and whose apparatus of collective bargaining coordinated the interests of workers and managers." This analysis was echoed in 1997 by Pierre Bourdieu in one of his rare pieces that focused solely on work: "The investment in labour, and therefore miscognition of the objective truth of labour as exploitation, which leads people to find an extrinsic profit in labour, irreducible to simple monetary income, is part of the real conditions of the performance of labour, and of exploitation." ${ }^{8}$ Bourdieu stressed the importance of the small spaces of freedom granted to workers, as a conquest or as a privilege.

History of the Present: A Journal of Critical History, Vol. 8, No. 2, Fall 2018.

Copyright (c) 2018 University of Illinois Press 
However exploited they may feel and actually be, women and men nevertheless bring their morals and affects to work with them. Just like E.P. Thompson's impoverished masses who ask a fair price for bread, instead of taking it for free, workers usually find it important to get the job done properly. ${ }^{9}$ Historians and sociologists of work have shown that workers have a hard time not being loyal to their trade, their company and even their employer-even when the job is literally killing them because of the hazards incurred; even when they are paid disgraceful wages; and even when they are treated disrespectfully. This loyalty allows for continued production and quality in industries that would have collapsed long ago, had workers decided to abide only by the rules on the books and keep their feelings out of the picture. ${ }^{10}$ Some risk their lives to preserve the means of production, like the seven workers who died in a steel foundry in 2007 in Turin, Italy, because they fought a fire instead of fleeing the premises as they had been instructed to do, only to be posthumously accused of negligence by their ungrateful employer. ${ }^{11}$ Even the fiercest political activists will bemoan their plant's closure or their company's bankruptcy, because they had come to develop a feeling of connection inextricably and emotionally tied to their jobs, however demeaning. ${ }^{12}$

It would seem that workers have little leeway when it comes to their moral involvement in work. The desire to see a job well done lives on even when the task is uninteresting and harmful to those who carry it out, as shown for example by workers in modern-day distribution centers. ${ }^{13}$ It is often impossible to perform one's craft correctly without a minimum of moral involvement. In their classic study of a French automobile plant in the $1980 \mathrm{~s}$ and 1990s, however, sociologists Stéphane Beaud and Michel Pialoux do describe a young generation of temp workers who keep their headphones on while working, do not speak to anyone, and leave promptly at the end of their shift. ${ }^{14}$ Through distancing workplace practices, these workers mean to show that in no way are they automobile workers like their fathers - a job that most of them have vowed never to embrace - and that they are only there because they need to make some money while they search for the elusive job of their dreams. While such a stance may be morally admirable, it is not sustainable in the long run, and some of these young men can become bitter, whether they remain in the job longer than expected or leave it suddenly even with no alternative. This contradiction is the cause of much suffering as long as it remains unresolved. 
Financial stakeholders have more latitude regarding their moral involvement in the businesses they operate. In the history of contemporary capitalism, owners of large companies have long given the impression that they, too, had a more than purely utilitarian relationship to their workforce and company. The set of practices that are usually labeled as paternalism illustrate this partly economic, partly moral relationship-one that advocates for worker dignity while enforcing stringent subordination and often making a profit from this so-called benevolence. ${ }^{15}$ Under this system, owners are expected to demonstrate that they care for their company as well as its profits, and that they know what kind of work is being carried out on the shop floor. This behavior is a pre-condition for public respect as well as for support by elected officials and the administrative state.

However, as of the 1970s-1980s, financial stakeholders seemed to have lost most of their moral stake in the businesses they owned, as the ideology of neoliberal economic policy caught on among the elite and was enforced in policies that placed profit over craft, and gave corporate power to investors who were disconnected from the reality of the work. Despite common trends, this history is specific to each country. The French case, which is the backdrop for this paper, is one of remarkably stealthy reforms - mostly carried out by economically liberal Socialists. These haveled to intense financial deregulation, or rather re-regulation, which has in turn granted relatively unfettered power to international investment funds with no moral involvement in the work that is being carried out. ${ }^{16}$

By 1984, France had instituted many changes including the abolition of the distinction between investment and commercial banks, the elimination of credit control, and the introduction of "new financial instruments such as money markets, commercial markets, and financial futures." ${ }^{17}$ No longer was government approval necessary for foreign direct investments. In 1990, all capital controls were abandoned, in line with directives from the European Union. The share of foreign investors in the French market grew from twelve percent in 1990, to twenty-one and a half percent in 1993, reaching a level of thirty-five to forty percent in 1999 (and for the top forty corporations, this share then reached forty-five percent). In 2000, non-residents represented " $82 \%$ of all stock transactions, giving them full control over price formation on the stock market."18 These foreign investors were often administrators of pension and mutual funds. They typically asked for a fifteen percent-plus return on equity as well as minority shareholder power over corporate policy, 
with little or no consideration for the wellbeing of the workforce or the quality of the craft. Between 1997 and 2002, Lionel Jospin's Socialist-Communist coalition government, with Finance Minister Dominique Strauss-Kahn as its economic mastermind, basically granted investors the power they were asking for and more, authorizing, for example, stock options with very low taxes.

In 1999, Michelin, the French tire company, simultaneously announced that profit had risen seventeen percent since the previous year and that it planned to lay off 7,500 people to continue the improvement of its margins ${ }^{19}$. Asked to react, Prime Minister Jospin famously declared that "you can't expect the State to take care of everything" (Il ne faut pas tout attendre de l'État) but then had to backtrack because of the uproar. ${ }^{20} \mathrm{He}$ subsequently promised to regulate such "stock market" layoffs (licenciements boursiers). This promise was struck down in January 2002 by the Constitutional Council (Conseil constitutionnel) when it ruled that forbidding layoffs in profitable companies was a breach of the freedom of enterprise guaranteed by the 1789 Declaration of the Rights of Man and of the Citizen. However, French politicians from both the left and the right who wished to escape political responsibility didn't blame the founding fathers of the Revolution. Rather, they depicted the EU as the main villain behind the deregulation policies that France had been forced to enact, even though, on a private level, they were usually in favor of the EU directives, some of which they had even crafted themselves.

The more that business and political elites focused on financial activities, the less they seemed to care about either the reality of work or the plight of the workforce. In particular, blue-collar workers and their world gradually became invisible through "various forms of marginalization, occlusion and disqualification from the mainstream political and media discourses."21 There remained only a few sociologists to contend that the working class was still alive and worth studying. ${ }^{22}$

The "erasure" of labor prompted narratives on the steady improvement of working conditions. In France in 2009, a right-wing minister of labor could thus express his satisfaction that occupational hazards no longer involved people falling into blazing furnaces. According to Xavier Darcos, in the new, post-materialist service economy, the main problem had become what occupational medicine calls psychosocial risk factors, understood loosely as work-related depression and burn-out. ${ }^{23}$ But such an account is misleading. During the past century, prevention has effectively focused on accidents, 
especially fatal ones, yet it has consistently ignored the much larger, but mostly submerged, iceberg of occupational disease. In the United States, the Centers for Disease Control acknowledges on its website that "millions of U.S. workers are exposed to substances that have been tested as carcinogens in animal studies or found to be possibly carcinogenic in human studies," and that many more millions are exposed to substances that have never been tested. ${ }^{24}$ It is estimated that more than ten percent of the new cancer cases each year are caused by working conditions. ${ }^{25}$ In France, manual workers die on average six years before white-collar employees, ${ }^{26}$ and are twice as likely to develop cancer before the age of 65 , probably due to the cocktail of hazardous working conditions to which they are exposed. ${ }^{27}$ The steady rise of forms of temporary work, subcontracting, self-employment, and fragmented schedules-especially in "dirty, dangerous and demanding" jobs - are creating new hazards, as well as increasing the danger of existing hazards. ${ }^{28}$ In many trades, working conditions are worse today than they were forty years ago. ${ }^{29}$

In 1700 , the Italian physician Bernardino Ramazzini, considered the founding father of occupational medicine, lamented that "unfortunate laborers encounter severe disease in the very trades which they thought would provide livelihood for themselves and their families, and then die hating their thankless job." ${ }^{30}$ Yet today, this relationship between workers and the jobs that are killing them is more often one of love-hate. It is a relationship with a complex understanding of attachment, in all meanings of the word. This is visible in the drama of plant closings, where the amoral relationship to one's work that is advocated by neoliberals is nowhere to be found. When factories close, workers and their families shed real tears-because of their apprehension about the social death of unemployment, of the threat to their economic livelihood, but also, as is often described, because of the painful feeling that a chunk of their identity and history has been left behind on the shop floor. ${ }^{31}$ For workers, union representatives, policymakers, and social scientists, the debate on coercion and consent in the workplace can then become obscured by a somewhat romanticized nostalgia for the industrial work of the past..$^{32}$ Mourning the lost grandeur of industrial cathedrals and bringing manufacturing jobs back can then appear as a progressive, workeroriented agenda. However, this nostalgia ignores and obscures the long history of grievances expressed by the workers who were once employed in these trades. 
Keeping morals and affect out of the issue of occupational accidents and disease has been a longstanding goal of lawmakers. France's 1898 law on compensation for workplace accidents, like other compensation systems that developed throughout Europe around the same time and in some parts of the United States between 1910 and 1920, tried to convert an issue of justice into one of insurance. ${ }^{33}$ According to François Ewald, then a disciple of Foucault, this signaled the birth of the modern welfare state..$^{34}$ The implicit message behind these schemes was that "accidents happen" as a necessary byproduct of new technological risks, and that money suffices to compensate all damages incurred. ${ }^{35}$

What Ewald did not see, however, was that this move toward amoralization utterly failed. Still today, workers confronted with industrial disasters continue to express a sense of injustice, a feeling that their exposure to known and preventable hazards should have been prevented. Moreover, they discover, aghast, that there was a price tag all along for their disease or injury - that managers, experts, and bureaucrats in some way expected itwould happen. ${ }^{36}$ Victims need more than compensation benefits to remediate their loss, even though most often they haven't defined what true justice would look like. ${ }^{37}$

In this paper, I focus on the evolution of workers' moral relationships to their jobs, drawing on a study of French industrial glassworkers I conducted between 2013 and 2017, based primarily on interviews and documents collected by the workers themselves. ${ }^{38}$ These workers are almost all male, mostly born in France and of Italian and Spanish descent (second and third generation), and some of them are first generation immigrants from Algeria, Tunisia, or Morocco. They all worked in a factory in Givors, near Lyon, producing glass bottles and jars for the food and liquor industry, until the factory's closing was announced in 2001 and became effective in 2003. The two final years were ones of intense struggle against the closing, during which time the workers militantly declared their attachment to their jobs.

The workers had long known that they were in a very dangerous trade. However, they did not question their exposure to danger while it was encompassed in a broader, implicit moral contract which governed social relations within the factory. But the workers experienced a wave of economic restructuring from the 1980 s onwards that was accompanied by a multi-stage process which I call moral restructuring, one that ultimately transformed their conception of fairness. Eventually, most glassworkers 
came to the conclusion that disease should not have been part of their job, and that they were not violating the implicit contract by refusing the risk of disease as a condition of labor. They felt betrayed. From 2009 onwards, under conditions I shall describe, these same glassworkers initiated a new fight in which they denounced the dangerous former working conditions to which they had been exposed, and which they believed had harmed them. They asked for justice. This mobilization is ongoing.

The older implicit contract rested on a moral economy, in the sense of an economy of morals. It was a contract that concerned the workers' relationship to their jobs, their colleagues, the management, the company and its employers, and the values underlying and produced by these relationships. It was a contract intimately linked to economic issues such as wages and other financial benefits, but not strictly determined by them. It was also an expression of what E.P. Thompson calls the "popular consensus as to what [are] legitimate and what [are] illegitimate practices" at a given moment. ${ }^{39}$ The boundaries between legitimate and illegitimate exposure to workplace hazards moved along with the workers' perception of the degree of fairness with which they were being treated, as well as their conception of what would be, on their part, a loyal way to behave. The workers' sense that the implicit moral contract had been betrayed led to their reassessment of these boundaries of permissible risk. Just as environmental pollution can offer a window on present-day conservative politics in America, industrial disease can be used as a keyhole issue, through which to analyze the profound transformations of what used to be the more privileged and protected stratum of the working-class. ${ }^{40}$

\section{Fire fodder}

In May 1968, France was in turmoil. After many days of student unrest that culminated in heavy street fighting with the police, millions of workers organized spontaneous strikes across the country. Six days after the beginning of the strikes, in the glassworks of Givors, the leaders of the Confédération générale du travail (CGT), the majority trade union, wrote a leaflet in which they announced their decision to take part in this formidable movement: "Will we, glassworkers, keep out of this struggle? No!"41 Just like millions of other workers in France at the time, they asked for better pay and shorter working hours.

The next morning, the CGT leaders joined up with the representatives from the other union, part of the Confédération Française Démocratique du Travail 
(CFDT), and called for a strike of unlimited length. Management was barred from entering the factory. Union leaders wrote a precise plan that entailed reducing production of glass bottles and jars, without stopping the furnaces. Many workers were assigned to security patrols, to make sure that other workers were following procedures and that the machines were never at risk of being damaged. Every day, the striking workers played the trumpet of the famous musician Maurice André on the loudspeakers, to herald the transition from the night shift to the morning shift. In the sand dunes of silica dust, which is the main raw material used to make glass, they organized volleyball and pétanque tournaments. In the evenings, dance parties were held at the factory. Despite these unusual activities, an engineer who was allowed in the factory one day acknowledged that all the machines were impeccably clean, ready to be fired up to maximum capacity at a moment's notice. In June, as the prospect of a revolution died down at the national level under the combined influence of repression, moderate labor reforms, and elections that shifted the parliament to the right, work eventually resumed its normal pace.

None of the 1968 grievances concerned worker health and safety, working conditions, or occupational health, despite the fact that glassworks are notoriously dangerous places. Exactly a century earlier, the life expectancy of the glassworkers of Carmaux was low: "glassworkers considered themselves old men at forty and the high rate of death in the forty to forty-four age group, especially, seems to document their belief." ${ }^{42}$ The main hazards to which the workers were exposed included a highly dusty work environment, intense heat from the furnace, and diseases transmitted by the sharing of the blowpipe. ${ }^{43}$

At the turn of the twentieth century, two technological innovations radically changed the work process. Gas-fired furnaces, in lieu of coal-fired ones, allowed for continuous factory operation. For laborers who had, until then, worked mainly during the cooler hours of the night, this was the beginning of shiftwork around the clock, usually in three scheduled shifts: morning, afternoon, and night. The other invention came from an entrepreneur in the town of Cognac and an engineer in Ohio, in the United States. Claude Boucher and Michael Owens simultaneously developed semi-automatic machines that used compressed air to blow bottles and jars into molds that gave them their shape. Suddenly, glassblowers were no longer needed. This did not mean, however, that the new machines could operate alone. Constant 
worker presence was needed to help regulate the flow of molten glass and the rhythm of production, and workers were needed specifically to grease the molds every few minutes with mineral oil.

This new organizational structure of the glass factory, put in place during the first half of the twentieth century, has remained more or less the same until today. Shiftworkers can be assigned to the loading of raw materials, to the furnaces, to the molding machines, to quality inspection, to packaging, as well as to the dark basement where glass waste falls and is recycled back into the production cycle. Day workers are assigned to perform maintenance and repairs. Most of the main hazards of the job have remained: extreme heat, burns, noise, and the toll of shiftwork on the body. But new ones have also appeared: the risk of having a limb caught in the machines; the stress placed on joints by repetitive movements in the glass molding and packaging stages; the use of large amounts of asbestos for insulation (mostly substituted today by ceramic refractory fibers, also a suspected carcinogen); the presence of graphited motor oils which the heat causes to evaporate into a perpetual mist of carcinogenic polycyclic aromatic hydrocarbons (PAH); and strong acids used for surface treatment of the glass.

Glassworkers have long been aware that their job is dangerous. At the end of the nineteenth century, the infirmary of the Baccarat glassworks was full of workers with chronic lung disease and severe burns. ${ }^{44}$ In 1900, Léon and Maurice Boneff, two Socialist brothers who specialized in investigative reporting on working conditions, included a chapter on glassworkers in their book Les métiers qui tuent (Jobs that Kill). ${ }^{45}$ They coined the expression "la viande à feu," or "fire fodder," to describe the glassworkers' plight. ${ }^{46}$ At the beginning of the twentieth century, the national glassworkers union called for better ventilation, no working during the hottest hours in summer, and the end of nightshifts. ${ }^{47}$ When the 1968 protests began, none of these grievances had been met, except perhaps better ventilation and confinement in the raw material area, which had at least helped decrease the amount of airborne silica dust, which causes silicosis.

\section{A Part of the Job}

Georges, known as Jo, was an electrician and mechanic who worked on the machines. One day in October 1986, he seized a red-hot metal rod that had just been welded by another worker. His hand sustained a third-degree burn, but Jo refused to go to the hospital until the next day. This way, the company 
would not have to complete an official accident report, and so it would not risk insurance premium hikes because of negligence. That night, Jo had a hard time sleeping. He recalls his hand was spewing pus all over the sheets. The next day, a doctor in Lyon told him it was too bad he had not come right away, because the situation could have been solved very quickly, while now a more complex procedure was necessary. Jo told a former colleague and me this story some thirty years later, in 2013 , ten years after the factory closing. He did not claim that this was an unfair treatment, that he should have been able to get medical attention right away, or that he should have benefited from an official recognition of his workplace accident by the state health insurance. Jo made no distinction between the company's interest and his own. Rather, he presented this as an unfortunate episode resulting from a normal, legitimate practice, with a rather happy end thanks to the hospital doctor's skill.

For Jo and his colleagues, being exposed to danger almost never used to be considered unfair, or even considered at all. There were compensating forces at play; the glassworkers rightly considered themselves quite well paid relative to other blue-collar workers. Though they were no longer maitresverriers (master-glassblowers with apprentices), they still believed that their skill set them apart, and referred to themselves as verriers, glassworkers, instead of ouvriers, workers. Deskilling had given place to the delimitation of a new set of skills, through which they retained a sense of superiority. They felt pride in the high quality of production which they achieved, and in the recognition of this quality by their employers. They also felt that their employers were genuinely concerned with their living and working conditions. Marie Souchon, the wife of the factory owner in the first half of the twentieth century, was known for giving gifts to glassworkers on special occasions, like their children's Catholic baptism.

The CEO from the 1960s to the 1990s, Antoine Riboud, was revered for hanging around the factory floor, sharing cigarettes or a glass of wine with workers, slapping them on the back while they worked the machines. Glassworkers also considered union-led collective action as something that not only provided them with access to more compensation and benefits, but also imparted a sense of pride and strength. Strikes and jokes played on middle management were important, not only because of what such actions achieved, but also as a milestones of worker dignity that would be recalled again and again in later years. In the 1970s, Antoine Riboud himself made 
many speeches to industry leaders in which he acknowledged the importance of having strong unions in a company.

Nothing better symbolized the period than the institution of the comité d'entreprise. This was a union-run organization required by the state since 1945 in big companies, which gave workers a limited amount of control over strategic decisions but especially focused on leisure activities ${ }^{48}$. The financial report for 1970, two years after the French general strike, states that 5,000 francs were spent on the wreath that the CGT leaders placed every year on Marie Souchon's tomb in recognition of her past generosity. The rest of the money was used mostly for Christmas gifts to the workers' children and financial aid to needy families.

My intention here is not to paint a rosy picture of working-class life in France in the 1960s and 1970s. Most serious historians have by now discarded the popular narrative of the so-called Trente Glorieuses, the prosperous thirty years following the end of the war, by shedding light on the margins, the scaffolding, which allowed a more privileged sector to thrive..$^{49}$ The glassworkers of Givors were part of this particular segment of the working class, this so-called aristocracy of labor, which was then, and is still to a certain degree, at the center of discourses, scholarly analyses, and political action regarding the working class: these are relatively skilled workers employed in big factories with strong unions. But despite this visibility, under and around these workers lurked a less visible, more atomized group of other workers. Economists Peter Doeringer and Michael Piore gave a striking description of these two labor markets for the United States in 1970, which works as well for the French case ${ }^{50}$ : "jobs in the primary market possess several of the following characteristics: high wages, good working conditions, employment stability, chances of advancement, and equity and due process in the administration of work rules. Jobs in the secondary market, in contrast, tend to have low wages and fringe benefits, poor working conditions, high labor turnover, little chance of advancement, and often arbitrary and capricious supervision." ${ }^{51}$ In the eyes of workers, fairness is one of the measures of these worlds: equity and due process in the primary labor market, inequity and arbitrary decision making by management in the secondary labor market.

\section{Economic restructuring}

In 1996, the CEO of the former Boussois-Souchon-Neuvesel (BSN) company, rebranded two years earlier as Danone (Dannon for the US market), 
handed control over to his son, Franck Riboud. Very soon, the factory in Givors was notified that it must reduce its workforce from 400 to 230 workers within the next seven years. Franck Riboud secretly organized a leveraged buyout (LBO) in order to sell the glassworks division of the company in the most profitable way. This entailed creating a company in the tax haven of Luxembourg, jointly with a major private equity group, CVC Capital Partners, in order to buy the glassworks division with the help of a huge loan. This loan was to be reimbursed, with interest, by the glassworks division itself, thanks to the increased margins entailed by a massive restructuring scheme.

On April 10, 2001, Givors union leaders were informed that their factory would be closed immediately, thus putting an end to two and a half centuries of continuous glassmaking activity in the town. The CFDT and CGT unions both started a major fight against the closing. Despite their efforts, a little under two years later, they watched, powerless, as the last furnace was decommissioned for good. The American glassmaking giant Owens-Illinois Manufacturing then bought what was left of the French glass division, ensuring the profitability of Riboud's plan.

Understandably, and perhaps predictably, the former glassworkers of Givors I have met all express their hatred for their last CEO. From their viewpoint, he lived in a disconnected world of financial markets, tax havens, and luxury golf courses in the Swiss Alps. His main concern was for his shareholders, not his workers. The fact that he imposed new regulations drastically cutting the workforce, and that at the same time he increased the number of untrained temporary workers, meant that he had no idea of the conditions that were needed in order to ensure high quality production. In contrast, his father had been interested and knowledgeable about the tricks and constraints of glassworking, and he had been respectful of unions and workers, always placing the reality of work over that of balance sheets.

The workers' sharply drawn assessment of the differences between managerial regimes is not, however, entirely corroborated by the historical record. Antoine Riboud, it turns out, was not as immune to big finance as the glassworkers say. A year after the events of May-June 1968, Riboud the elder was the first CEO in France to experiment with a hostile financial takeover of his main competitor, Saint-Gobain, an attempt that ultimately failed. From that day on, however, his interest in the glassworking industry steadily waned. Internal memos show that he wished to divest gradually from the packaging industry, in order to concentrate solely on food and water. In the 1980s, he 
was once again one of the first French entrepreneurs to use an LBO. One can argue that the closing of the Givors factory was the final stage in a thirty-year process in which strictly financial schemes always played an important part. The workers retrospectively condoned Antoine's actions, probably because he seemed to uphold the terms of the company's moral contract, contrary to his son who did not even try to disguise his financially minded motives.

During the same period, management styles shifted in the Givors glassworks, just like in other industrial workplaces around the world. ${ }^{52}$ For market and ideological reasons, the way in which one was supposed to work was no longer precisely dictated from the top down but was instead determined by the workers' own skills, initiative, and sense of responsibility. Workers were surprised to discover that top management, and even foremen, no longer knew the particulars of their jobs. Their work was still closely monitored and controlled, but now according to abstract, sometimes absurd, nonsensical guidelines, which seemed to have been created and implemented mostly to give an impression of quality control. The worker autonomy that was heralded on the one hand was thus severely undermined on the other hand by increased turnover, reduction of manpower, and reliance on temporary workers and subcontractors, all of which further disorganized the workplace. In the Givors glassworks, management seemed to have lost all pride in the complex skills that were being deployed daily, as illustrated by the episode in the 1980 s when workers who had asked for a supply of free drinking water to alleviate the effects of the extreme heat on the shop floor (the BSN group then owned most of the major French mineral waters) were at first provided with plastic bottles, because they were supposedly cheaper. Facing the workers' mounting anger, the company eventually reverted to supplying the glass bottles that were manufactured in BSN plants.

Had the factory been closed for reasons of low quality, low market demand, or superior performance by the competition, the workers would most likely not have considered it to be an act of betrayal. What the glassworkers did not-and could not-accept was that a thriving factory with high quality production should be closed for the enrichment of a few dozen shareholders with bank accounts in Luxembourg. From the glassworkers' perspective, the ultimate act of betrayal was the 2001 letter that Franck Riboud sent to Elisabeth Guigou, the Minister of Employment and Solidarity (this was the name the Jospin socialist government had given the Ministry of Labor), a few months into the struggle over the closing of Givors. In it, he claimed 
that the glassworkers who had called on her were mistaken: he had nothing to do with their company. ${ }^{53}$ The glassworkers, who were as respectful of the machines during this strike as they were in 1968, came to a disheartening conclusion: they were the last ones who still cared for the Givors factory and, more generally, for the craft of glassmaking.

After a year of demonstrations, decreased production, and calls for political support and legal action, the union leaders announced in March 2002 that all alternatives had failed: the factory was doomed. The only thing left to do was to negotiate the terms of the closing. At this point, the workers split into two groups. Some felt so bitter that they expressed a desire to burn everything to the ground. Their impulse was checked by other colleagues, who insisted on keeping the machines running smoothly, which they felt would help negotiate a better deal. The closing settlement that was eventually reached was a success, in a sense. It was the dying gasp of the implicit moral contract that had until then, in the workers' view, governed their relationship to their work. All workers were offered compensation, at levels that were a little over what was required by law, and most obtained new jobs elsewhere through the help of their former company, though the jobs were usually less stable and less well paid. Those who were fairly close to retirement age were allowed to receive unemployment benefits without having to search for another job.

More surprisingly, the comitéd'entreprise lived on. An organization of former glassworkers was created, headquartered in an apartment which had been donated by the company. Through it, the former workers continued to organize some of the leisure activities they had enjoyed when employed by the company. To this day, many of them still spend a yearly week of vacation together on the Mediterranean shore. The organization of former glassworkers was also able to continue providing the negotiated low premiums of the mutual health insurance plan they had hitherto enjoyed, which was very much appreciated as a way to supplement state medical insurance.

\section{Attacking the Glassworks}

Christian Cervantes (1948-2012) was one of the main officers of the CGT trade union, who had led the struggle to keep the factory open. His friends compared him to Asterix the Gaul, because of his mustache and his eagerness to jump into difficult struggles. When the factory closed in 2003, he was fifty-five, and therefore could be included in the pre-retirement package. $\mathrm{He}$ spent time riding his bicycle, fixing up his house and garden, and fighting on 
behalf of his younger former colleagues, a lot of whom were provided only with unstable employment. With his union comrade André Vizioli, he was also thinking of opening a museum of the glassworks in Givors-a space in which the machine parts, glass objects, and archives that they were able to save could be exhibited.

In 2005, a lump in his throat was diagnosed as cancer. He started intensive chemotherapy and had to undergo an operation with lasting, disabling effects. A few years later, doctors found another cancerous tumor in Christian's mouth. He once again underwent intensive treatment and a major operation, which this time removed part of his jaw, making it very difficult for him to speak or swallow.

In 2009, around the time that Christian was diagnosed with his second cancer, his wife Mercedes got in a row with him and some former colleagues who had come to visit. She criticized them for not seeing that they were all dying, and for not wondering why this was happening. All of them knew countless glassworkers who had died of cancer or cardiac arrest at a young age, before and after the closing. For Mercedes and for her two daughters, one of whom was a nurse, this was not normal and was most probably caused by conditions in the glassworks. As a first step, they asked Christian to conduct a survey of the 600 members of the organization of former glassworkers, in order to get a clear picture of who was sick, and who died at what age. Because of the health plan, the organization had a precise list of all home addresses.

But Christian refused to undertake this inquiry. That evening, he asked his wife why she was "attacking the glassworks." ${ }^{54}$ As one of his daughters told me later, his line of conduct had always been that "you should not bite the hand that has fed you" which, interestingly, is a variation of a proverb in which "feed" is usually used in the present tense.$^{55}$ Christian thought this was a matter of loyalty. And moreover, he considered an inquiry into the dangers of the job to be at odds with all the efforts he and his colleagues had made to keep the factory open. At this point, despite all the economic restructuring that took place, it seemed that Christian and his former colleagues still stuck to the past implicit moral contract.

Nevertheless, he perhaps harbored some doubts, as illustrated by the fact that, even though he refused to carry out the survey himself, he finally agreed to hand over the list of addresses to his wife and daughters. They crafted a two-page questionnaire that was sent out to the 600 members. One third of them responded. More than 90 cases of cancer were reported 
in these roughly two hundred answers, as well as many instances in which former glassworkers died at relatively young ages. In the following years, Mercedes and her daughters worked with an outstanding local activist and intellectual, Laurent Gonon, a seventy-year-old former printer and member of the Communist party, who helped them build a very strong case that glassworkers had been poisoned by their work. ${ }^{56}$

Thanks to a mix of intensive historical research to document past working conditions and exposure to cancer-causing agents, pro bono work on the part of activist physicians and lawyers, and strong media coverage and political support mainly from the left, the appeals court of the state compensation system eventually recognized that Christian Cervantes's two cancers had been caused by his work. Unfortunately, this recognition took seven years, and came three years after his death at age 64 .

In his final years, Christian Cervantes had become a vocal member of the struggle, despite his difficulty speaking. His disfigured face appeared in national newspapers and on local television. Something had caused Christian's definition of loyalty to shift. This was obvious in a letter he sent to Xavier Bertrand, the Minister of what was now known as Labor, Employment and Health, one month before his death in 2012: "I am especially fighting so that someone will show some interest for us ... for my colleagues who are still exposed, who will die if nobody does anything [....] Something must change, or else tomorrow our children, our grandchildren, when they work in the same jobs as we used to, will suffer the same fate [.... To remain silent is to endorse this. That is why, to the contrary, I make this widely known, because I do not want to be complicit in the murder of my comrades." ${ }^{57}$

He was not the only one to have changed his position. In the years following the 2009 questionnaire, a group of almost one hundred former glassworkers became very active in the mobilization for justice which was carried out under the aegis of the organization. These were, more or less, the same people who had been at the forefront of the fight to keep the factory open just a decade earlier.

\section{Moral restructuring}

Undoubtedly, both the shift in the work organization and the shocking way in which the factory was closed were two conditions of possibility for the moral restructuring that the glassworkers underwent. However, other ingredients were also needed for them to get to the point where they felt that in fact they 
had not been fairly treated, and that they could denounce their working conditions while remaining loyal to their craft and to their identity as glassworkers.

Probably the most important of these ingredients was the part played by their spouses, all women. In Givors as elsewhere, industrial glassworking was a trade which almost exclusively employed men. The few women in the factory worked in strictly limited areas: quality control, packaging, and administration. This job segregation by gender was usually legitimized by speaking about the danger and physical demand of the jobs in the part of the factory called the "hot sector," reserved for men, in contrast to the safer jobs of the "cold sector," where women were permitted to work..$^{58}$

Equal treatment for men and women was not part of the union's repertoire. In this mostly male workforce, different and higher wages for men were considered part of the fair deal. This was true in an economic sense, of course, as men were paid better than women. But there was also symbolic gratification, because of the valor which came from working with fire and sand, from the glassworkers' breadwinner status in their own families, and from the closely knit working teams which resulted from a shared sense of the rightfulness of male domination. For the glassworkers of Givors, similar to the automobile workers of Peugeot Sochaux, "solidarity [was] constructed in everyday working practices in which the body [was] deeply involved," and the workers' "social personality [was] shaped in the factory by a particular type of physical effort and in a logic of confrontation with supervisors." 59

The glassworkers' wives had a more ambivalent relationship to their husbands' work. The glassworks formed the basis of the organization of their family life as well as their social life. Domestic order followed the rhythm of shiftwork. Members of glassworker families were friends with members of other glassworker families. The wives of glassworkers took care of housework and the children, and when they worked outside the home, it was in jobs with short or fragmented hours, low pay, and low status.

The women were the first to turn against the glassworks because they were the primary accountants of their families' wealth, health, and status. ${ }^{60}$ They would have probably consented to fewer sacrifices before the closure if their husbands' jobs had been less well paid or less prestigious. They were therefore the first to realize that sacrifices were no longer being fairly compensated. Moreover, the legitimacy of the patriarchy to which they had been subjected for most of their lives rested on the performance of their husband's manliness both inside and outside of the workplace. This image 
was shattered when men fell sick, when their bodies were weakened and mutilated by drugs and surgery, or when they could no longer eat or go to the bathroom alone. ${ }^{61}$

In the interviews I conducted with glassworkers' spouses and widows, they spoke of their husbands' manliness as a theatrical part they played, rather than an essence they exhibited: "il faisait très homme" (he very much looked/performed manliness).$^{62}$ Nevertheless, the women were intent on upholding the plausibility of this manly role, for their husband's sake, and for the sake of the order that structured the community. For example, Christian's reputation was one of a combative union leader, one who wore his small victories against management as badges of honor. Therefore, Mercedes wanted to help him win yet another battle, so that he could show he had gotten the upper hand even in the injustice of his ill-health. He only won this battle posthumously.

\section{Confronting injustice}

More than a century earlier, in July 1895, the glassworkers of Carmaux declared a strike. Until then, the relationship between the union and the owner, Rességuier, had been a rather cooperative one: "As long as the union aided Rességuier within the glassworks, he had allowed it to exist. Relying on the skill and standards of his souffleurs (glassblowers), he permitted them to supervise the hiring and firing of employees. The union enforced factory discipline as well as union regulations and, as a result, Rességuier found his plant more efficiently run. ${ }^{63}$ By 1895 , however, this cooperation was no longer the case, as illustrated by Rességuier's firing of one of the union leaders, which sparked the worker mobilization. The owner tried to break the strike by declaring a lock-out, and then hiring non-unionized workers from other glassworks. In October, the wives of striking Carmaux glassworkers gathered in front of the factory and yelled to the new recruits: "If you are going to work because you need bread, we will give you bread." ${ }^{64}$

Yet Rességuier ultimately won. Almost all members of the union were fired, and went to Albi to start a new, cooperative glassworks with the political support of Socialist deputy Jean Jaurès. According to Joan Scott, "Rességuier's victory also demonstrated the ultimate futility of the glassworkers' cause. He could fire every souffleur in his factory because they were easily replaced by cheaper, less skilled, and less demanding workers." ${ }^{75}$ In the following years, deskilling because of technological transformations and 
the correlated decrease in union power lowered the status of glassworking, bringing it closer to other semi-skilled jobs, even though wages remained comparatively high, especially for those just entering the trade.

At a century's distance, the story of the glassworkers of Givors echoes in many ways that of their Carmaux ancestors. One of the main parameters of the struggle against successive waves of economic restructuring was management's growing disdain for the unions' bargaining power. Just as mechanization and deskilling had made the glassworkers of Carmaux, and in particular the souffleurs, dispensable, in twenty-first century France the rising profitability of playing the stock market had diminished the workers' importance as a factor in making business decisions. When the decision to close the factory was announced, the glassworkers of Givors designed a plan to expand production far beyond what it had previously been, based on blueprints that were smuggled out by complicit engineers. The owners were not willing to listen to them, however, and there were no politicians who appeared to lead them to start a factory of their own.

On the national scene, it became obvious in January 2002 that the Gauche plurielle of Socialists and Communists would not uphold its promise of the passage of a law forbidding the closing of a profitable factory. In Givors city politics, the Communist establishment supported the negotiated settlement by promising an industrial revitalization of the abandoned estate. Fifteen years later, little has been built beyond large, empty parking lots. At the time of my study, none of the former glassworkers were active in Communist party politics and only a few participated actively in unions, though many had been active in the past. A few voiced their support for the far-right politics of the National Front, mostly as a convenient way to do away with the ruling elite, but the majority simply expressed their disgust for mainstream politics, from which they no longer expected anything.

The driving force of the glassworkers' struggle against hazards and disease was their profound sense of injustice, rather than a clear view of what justice looked like. Just as they considered that their employer did not have the right to close the factory, as many of them relentlessly repeated to me, they questioned the legitimacy of their long-term exposure to hazards that had been well known to management. Distinguishing between types of harm - the harm caused by the factory closing and that caused by exposure and disease-was far from simple. In one lawsuit at the labor court, sixty former glassworkers asked for compensation for the anxiety they experienced 
because of their former exposure to carcinogens, even though they were not sick (yet). Their lawyers asked them to draft written testimonies describing the everyday symptoms of this fear, in which they then censored any mention of the trauma due to the closing, lest this be used against the plaintiffs.

The glassworkers were confronted with institutions of distributive justice that purported to fix the disorder of industrial disease through the allocation of meager compensation, rather than punishment of those at fault. Their lawyers warned them that punishment was something that was almost impossible to obtain in the decriminalized world of workplace death, ${ }^{66}$ or what the Italians call "mortibianche," white deaths. ${ }^{67}$ At first, the glassworkers did not question the system. Christian Cervantes and a handful of his colleagues applied for compensation benefits from the state-sponsored, industry-financed insurance plans. Such action was far from revolutionary. It was, instead, just a way to claim the fringe benefits that had been part of the implicit economic and moral contract of the glassworks, much the same as when the factory had closed and the workers had asked for the paid vacation they were entitled to.

Just as the deputies of 1789 became revolutionary because of the way they were treated by Louis XVI, the glassworkers of Givors were transformed by their interactions with physicians, judges, and lawyers. ${ }^{68}$ Michel, a mechanic at the glassworks between 1967 and 2003, was diagnosed with bone cancer a few years after the factory closing. When his wife Marie-Thérèse and he went to see the occupational disease specialist for the greater Lyon area, because his approval was needed to begin the compensation procedure, the first thing the renowned professor asked them was: "So, I gather you need money?" Taken aback, Marie-Thérèse and Michel responded that they had savings, that they needed nothing - this was their right. Yet, understandably, they felt deeply humiliated.

Interviews with glassworkers are rife with such stories. Even when they seemed better inclined, the medical and legal professionals that the glassworkers confronted in their quest for compensation would routinely admit that yes, it seemed they had been exposed to such toxic product, and yes, there were epidemiological studies that showed that exposure to that product caused an increase of a certain type of cancer, which just so happened to be the cancer that was afflicting them. However, the experts would then state that this was not proof enough. They needed proof that, in this particular case, their disease had been caused by the work in the factory, and by nothing else. This is of course impossible to prove, whatever the circumstances. The 
workers' relentless efforts eventually did pay off for some of them, however. Many sick glassworkers were recognized as displaying the symptoms that made them eligible for the compensation program. But this did not help heal their wounds. To the contrary, it was considered added evidence that, from the start, the judiciary's rulings had been arbitrary and absurd.

Luckily, the fight against injustice also has its blessings. In order to defend their claims, the former glassworkers have had to provide written and oral testimony that describes the tasks they used to carry out in the factory. Documenting the hazards of the job is a way to celebrate rather than desecrate their former craft. It gives them an opportunity to demonstrate their intimate knowledge of their former job, more than a decade after the factory's closing, while facing upper-class lawyers from Paris and Lyon who have never set foot in a factory. When they leave for the hearings as a group, in the bus which is provided to them free of charge by the mayor, it reminds them of the time when, to protest the closing, they barged in uninvited in the midst of a prestigious tournament on Franck Riboud's golf course.$^{69}$ As long as the proceedings last, they are glassworkers once again.

Previousversions of this paper were presented in 2017 at the weekly seminar of the School of Social Science of the Institute for Advanced Study in Princeton; the CNRS-NYU joint research center in New York City; the history reunion of the International Committee on Occupational Health, hosted by the University of Göteborg; the Rapoport Center for Human Rights and Justice at the University of Texas at Austin. I thank all participants in these presentations as well as Céline Bessière, Nick Cheesman, Karen Engle, Didier Fassin, Julius G. Getman, Paul Jobin, and the editors of History of the Present for their hearty encouragement, inspirational comments, scrupulous criticism and wonderful editorial work.

Pascal Marichalar is a sociologist and historian with the French National Center for Scientific Research. His research deals with justice, health, work, and industrial pollution. He recently published Qui a tuéles verriers de Givors? Une enquête de sciences sociales (Paris, La Découverte, 2017).

\section{Notes}

1. Elizabeth Kolbert, "Why Work? A Hundred Years of 'The Protestant Ethic," The New Yorker, November 29, 2004.

2. Christopher Adair-Toteff, "Statistical Origins of the 'Protestant Ethic,"' Journal of Classical Sociology 15 (2014): 59-60.

3. Isabelle Kalinowski, “Le capitalisme et son 'éthique': une lecture de Max Weber," Agone 33 (2005): 253-264.

4. Max Weber, The Protestant Ethic and the Spirit of Capitalism (2002), 121. 
5. Max Weber, "Zur Psychophysik der industriellen Arbeit," in Gesammelte Aufsätze zur Soziologie und Sozialpolitik (1988), 61-255.

6. Michael Burawoy, "Donald Roy - Sociologist and Working Stiff," Contemporary Sociology 30 (2001): 454 .

7. Ibid., "'Manufacturing Consent' Revisited," La Nouvelle Revue du Travail 1 (2012): 10.4000/nrt.143.

8. Pierre Bourdieu, Pascalian Meditations (2000), 202.

9. Edward Palmer Thompson, "The Moral Economy of the English Crowd in the Eighteenth Century," Past and Present 50 (1971): 112-114.

10. This is, for example, the case in French nuclear power plants. Pierre Fournier, Travailler dans le nucléaire. Enquête au coeur d'un site à risques (2012).

11. For a description of the Turin ThyssenKrupp 2006 fire, and the criminal trial that followed, see Annie Thébaud-Mony and François Lafforgue, "Industrial crimes and the criminal justice system: experiences from continental Europe," Policy and Practice in Health and Safety 11 (2013): 81-89.

12. Collectif du 9 août, Quand ils ont fermél'usine. Lutter contre la délocalisation dans une économie globalisée (2017).

13. David Gaborieau, Des Usines à colis. Trajectoire ouvrière des entrepôts de la grande distribution, $\mathrm{PhD}$ thesis, Paris 1 University (2016).

14. Stéphane Beaud and Michel Pialoux, “Between 'Mate' and 'Scab': The contradictory inheritance of French workers in the postfordist factory," Ethnography 2, no. 3 (2001): 323-355.

15. Gerald Zahavi, "Negotiated Loyalty: Welfare Capitalism and the Shoeworkers of EndicottJohnson, 1920-1940," The Journal of American History 70, no. 3 (1983): 602-620.

16. All data in the two following paragraphs from Yves Tiberghen, Entrepreneurial States: Reforming Corporate Governance in France, Japan, and Korea (2007), especially chapter 3 "France: Effective but 'Shameful' Reforms," 64-103.

17. Ibid., 69.

18. Ibid., 77.

19. Ibid., 96.

20. "Journal de 2oh" (8 p.m. newscast), France 2, September 16, 1999.

21. Jackie Clarke, "Closing Moulinex: Thoughts on the Visibility and Invisibility of Industrial Labour in Contemporary France," Modern and Contemporary France 19 (2011): 443-458.

22. Rick Fantasia, Cultures of Solidarity: Consciousness, Action and Contemporary American Workers (1988); Stéphane Beaud and Michel Pialoux, Retour sur la condition ouvrière: enquête aux usines Peugeot de Sochaux-Montbéliard (1999).

23. Xavier Darcos, French Minister of Labor, speech given on October 9, 2009.

24. https://www.cdc.gov/niosh/topics/cancer/ (accessed on March 20, 2017).

25. Kurt Straif, "The Burden of Occupational Cancer," Occupational and Environmental Medicine 65 (2008): 787-788.

26. Nathalie Blanpain, "Les hommes cadres vivent toujours 6 ans de plus que les hommes ouvriers," Insee Première 1584 (2016). 
27. Gwenn Menvielle, Annette Leclerc, Jean-François Chastang and Danièle Luce, "Inégalités sociales de mortalité par cancer en France: état des lieux et évolution temporelle," Bulletin épidémiologique hebdomadaire 33 (2008): 289-292.

28. Sara A. Quandt et al., “3-D Jobs and Health Disparities: The Health Implications of Latino Chicken Catchers' Working Conditions," American Journal of Industrial Medicine 56 (2013): 206-215.

29. On the French case, Michel Gollac, Serge Volkoff and Loup Wolff, Les conditions de travail (2014); Annie Thébaud-Mony, Travailler peut nuire gravement à votre santé (2007).

30. Bernardino Ramazzini, De morbis artificum diatriba (1700), my translation.

31. Paul Blyton and Jean Jenkins, "Mobilizing resistance: the Burberry workers' campaign against factory closure," The Sociological Review 60:1 (2012): 25-45.

32. Bill Bamberger and Cathy N. Davidson, Closing: The Life and Death of an American Factory (1998); Danièle Linhart, Barbara Rist and Estelle Durand, Perte d'emploi, perte de soi (2002); Frédéric Fajardie, Metaleurop, paroles ouvrières (2003).

33. Julia Moses, The First Modern Risk: Workplace Accidents and the Origins of European Social States (2018).

34. François Ewald, L'Etat-Providence (1986).

35. Michael C. Behrent, "Accidents Happen: François Ewald, the 'Antirevolutionary' Foucault, and the Intellectual Politics of the French Welfare State," The Journal of Modern History 82:3 (2010): 585-624; Julia Moses, The First Modern Risk: Workplace Accidents and the Origins of European Social States (2018).

36. Anne Marchand, "Quand les cancers du travail échappent à la reconnaissance. Les facteurs du non-recours au droit," Sociétés contemporaines 102 (2016): 103-128.

37. Judith N. Shklar, The Faces of Injustice (1990).

38. I am heavily indebted to the glassworkers of Givors, their relatives as well as the historian, activist, and my good friend, Laurent Gonon. Full details of this work are in Pascal Marichalar, Qui a tuéles verriers de Givors? Une enquête de sciences sociales (2017).

39. Thompson, "The Moral Economy of the English Crowd in the Eighteenth Century," 79.

40. Arlie Hochschild, Strangers in Their Own Land:Anger and Mourning on the American Right (2016).

41. “Tous dans la lutte!” May 19, 1968.

42. Joan Wallach Scott, The Glassworkers of Carmaux: French Craftsmen and Political Action in a Nineteenth-Century City (1974), 43.

43. Ibid., 42.

44. Caroline Moriceau, Les douleurs de l'industrie: l'hygiénisme industriel en France, 1860-1914 (2008), 23.

45. Léon and Maurice Bonneff, Les métiers qui tuent: enquête auprès des syndicats ouvriers sur les maladies professionnelles (1900).

46. Ibid., "Les travailleurs du feu," La Nouvelle Revue, June 9, 1906.

47. Moriceau, Les douleurs de l'industrie, 236. 


\section{Moral Restructuring in a French Factory}

48. This institution was disbanded in 2017 under President Emmanuel Macron, and replaced by a "social and economic committee" whose exact function is yet to be defined.

49. Céline Pessis, Sezin Topçu and Christophe Bonneuil, Une autre histoire des "Trente Glorieuses": modernisation, contestations et pollutions dans la France d'après-guerre (2013).

50. Claude Picart, "Une rotation de la main-d'œuvre presque quintuplée en 30 ans," Insee Emploi et salaires (2014): 29-45.

51. Peter Doeringer and Michael Piore, Internal labor markets and manpower analysis (1970), 271-272.

52. Philippe Davezies, "Lindividualisation du rapport au travail : un défi pour le syndicalisme," European Trade Union Institute Policy Briefs (2014).

53. Franck Riboud to Elizabeth Guigou, October 15, 2001.

54. Interview with Mercedes Cervantes, October 15, 2013.

55. Interview with Sonia Cervantes, February 4, 2014.

56. Laurent Gonon, "Maladies professionnelles des verriers : le déni des droits," Journal de médecine légale 58 (2015): 343-367. Laurent and I have also closely collaborated on many aspects of this research.

57. Christian Cervantes to Xavier Bertrand, January 23, 2012.

58. Karen Messing, Katherine Lippel, Diane Demers, and Donna Mergler, "Equality and Difference in the Workplace: Physical Job Demands, Occupational Illnesses, and Sex Differences," National Women's Studies Association Journal (2000): 21-49.

59. Beaud and Pialoux, "Between 'Mate' and 'Scab," 350.

6o. Phil Brown and Faith I.T. Ferguson, “'Making a Big Stink': Women's Work, Women's Relationships, and Toxic Waste Activism”, Gender and Society, 9 (1995), 145-172.

61. Angela Turner, "Corps meurtris. Genre et invalidité dans les mines de charbon d'Écosse au milieu du dix-neuvième siècle," in Santéet travail à la mine:XIXe-XXIesiècle, ed. Judith Rainhorn (2014), 239-26o.

62. Interview with Mercedes Cervantes, June 28, 2016.

63. Scott, The Glassworkers of Carmaux, 145.

64. Ibid., 153.

65. Ibid., 164 .

66. W.G. Carson, "The Conventionalization of Early Factory Crime," International Journal of the Sociology of Law 7 (1979): 37-60.

67. Italian Senate, Report of the Commissione di inchiesta sul fenomeno degli infortuni sul lavoro con particolare riguardo alle cosiddette "morti bianche" (2008).

68. Timothy Tackett, Becoming a Revolutionary: the Deputies of the French National Assembly and the Emergence of a Revolutionary Culture (1789-1790) (1996).

69. "VMC: la lutte finale," Le Progrès, 17 juin 2001. VMC (Verreries mécaniques champenoises) was the name of the entity within BSN-Danone which operated the Givors glassworks. 